\title{
analytical presentation of the latest local and international research based on models and theories of general practice in social work to activate social welfare services for the academically outstanding
}

\section{Anwaar. R. Mohammed Elsayed (Ph.D.)}

Associate professor Umm Al Qura University Al-Leith University College - Department of Social work 
analytical presentation of the latest local and international research based on models and theories of general practice in social work to activate social welfare services for the academically outstanding

\section{Abstract:}

The research aimed at analyzing local and international research and studies using models and theories of general practice in social work to activate social welfare services for the academically outstanding, analysis of the latest Arabic and foreign research and studies that it addressed to activate social welfare services for the academically outstanding quantitatively and qualitatively, (63) studies were analyzed of which (51) Arabic and (12) English, some recommendations were concluded after analysis It is useful to searcher for social work.

KEY WORDS: social welfare services - outstanding students- - academically outstanding

\section{Introduction:}

In the present era, societies are racing in all fields in pursuit of progress and sophistication, and in return, man in this age faces many challenges that may hinder progress, as progress and the achievements of the human brain have led to aspects that were not all positive, but resulted in some negatives that represent a challenge, and some imbalances that hinder the progress of humankind. There has been an imbalance in the environment in which human beings live, and attention to, care and good channeling of human resources are by creating all possible opportunities to take care of them, their talents, trends and positive creative tendencies, mentally, practically, psychologically and socially (Abdul-Ghaffar, 2003, p. 171).

School is one of the means of interest in the human element and has a role in achieving psychological, social and mental development, and it has now become dependent on the efforts of social workers directly and may need their services at another time outside it. School may face multiple and complex individual problems in more need of individual social efforts, and the school may need a social system to ensure homogeneity and collective activity that requires social work efforts and practice with different patterns in the field of school (Abdul-Fattah,2014, p.102).

As a social institution, school performs a range of educational, pedagogical and social functions to achieve its goals and care for its students by helping students to satisfy their needs, advising the school administration, organizing groups of parents and the community, using other disciplines to provide services to students, formation and development of ties and connections between school and institutions that provide social care to students (Mohammed, 2001, p. 282,283).

The academically outstanding are important in society. An obvious matter that needs to be emphasized is that human resources are the best investment, and more useful and more beneficial than all other material resources if they are well prepared and exploited and if they are used in developing and increasing production. Countries are superior through their talents and their creatives, and are ahead of other countries 
with the minds of their scientists and inventors, but those countries that depend solely on owning material wealth will lag behind and will not achieve renaissance unless their revenues are used to create programs to detect the outstanding and the creative (Gaddafi, 2000, p. 22).

Social welfare for the outstanding is a necessity and an important task of contemporary societies, as it has become clear that the role educational institutions working on socialization, especially families, has reduced and thus it has become clear how important it is to improve the standard of living and provide various aspects of care to members of society in general and caring for the outstanding in particular (Mansour, Ahmed, 2000, p. 59).

The process of providing social welfare within the school - as an open pattern - within the framework of its openness and interaction with the surrounding patterns, is essential for students and for the development of their lives and stability. If the services and care provided to students must be based on specialized and studied scientific and professional bases, their planning and organization to the category of outstanding ones in particular must be based on specialized professional efforts that take into account the characteristics, needs and problems of this category, these outstanding students are the scholars and scientists of the future, the builders of renaissance and society leaders, and the scientific and professional interest in them is an interest in the human resources that society needs to build itself and promote different fields of work.

Social work seeks to bring about deliberate changes in individuals, directing its efforts to develop the capabilities of the outstanding individuals and invest all their abilities, and provide direct and indirect services within the scope of its cooperation with other professions to help the outstanding to reach the desired level of services.

One of the recent trends that has emerged in the practice of social work is the trend of general practice, which is seen as the trend of professional practice in which the social worker concentrates as a general practitioner on their work at school and on dealing with the situation they deal with in a comprehensive and integrated way whose parts or components are not separated, but deals with all these components and exchange and interaction that occur between them without any attempt to break up the situation or specify practice since the focus of the general practitioner's attention is the school phenomena and problems and the issues that they deal with.

At school, pupils face problems that are evident in the interaction between each other and between other patterns and aspects of the school community, which hinder efforts by the school pattern to create a suitable social environment to achieve goals and take advantage of different activities to influence their personalities to reach social maturity and develop the abilities and potential of students who are academically outstanding and invest them well for the well-being and advancement of society (Habib, 2014, p. 403, 404). 
The general practice with its different models improves the relationship between the individual (the academically outstanding student and the attitude to which he or she is exposed, so it is more effective in dealing with human needs and problems, as it stimulates human capabilities to improve. (Germain, Gitterman,1980)

In the light of the above, the problem of current research is determined by the following questions:

What are the contributions of global studies and research using scientific models of general practice to activate social welfare services for the academically outstanding? and the following sub-questions emerge from this general question: -

1- What are the latest scientific research and studies that have been interested in using models and theories of general practice in the social work to activate social welfare services for the academically outstanding?

2- What are the results of quantitative and qualitative analysis of the latest research and scientific studies that have been interested in using models and theories of general practice in the social work to activate social welfare services for the academically outstanding?

3- What are the most important conclusions of the latest research and scientific studies that have been interested in using models and theories of general practice in the social work to activate social welfare services for the academically outstanding?

\section{Research goals}

1- Analysis of the latest Arabic and foreign research and studies that it addressed to activate social welfare services for the academically outstanding quantitatively and qualitatively.

\section{Concepts of research}

\section{Concept of social welfare services}

The Social Work Dictionary defines it as "a national pattern of programs, services and aids to help people meet their social, economic, educational and health needs and is essential to the preservation of society and a state of social well-being of society (Barker,1999, p192).

It is also defined as "a complex system of social systems that includes a wide range of professions and businesses that are interested in helping people by providing the types of services directed to meet needs, improving the standard of living of members of society, improving their social performance to achieve social stability, bringing about social change and consolidating and strengthening social control for the well-being of people in society (Ali, 2009, p. 130).

The concept of social welfare services for outstanding students can be defined as 
The psychological, social, recreational, educational and cultural services package for outstanding students and their families aiming at protecting them, satisfying their needs and solving their problems.

\section{The concept of the academically outstanding}

The outstanding are defined as those with a mental or academic ability that makes them able to learn faster than their mates at the same stage and they have the motivation to do so (Wahba, 2007, p. 14).

The academically outstanding are also defined as all those who have outstanding special abilities and are distinguished from their peers in their performance and reach a high and continuous superiority at an aspect of human activity, whether academic or non-academic, and characterized by mental superiority based on genetic and environmental factors that assist in its formation and development (Zahran, 2003, p. 107-108).

The academically outstanding are defined as the ones whose performance has reached a higher level than the ordinary in one of the areas that reflect the mental and functional level of the individual provided that this area is appreciated by the community (Suleiman, Munib, 2008, p. 20)

The academically outstanding are defined as the ones who are distinguished from their mates, they surpass them in school and get higher grades than they get and are usually smarter and faster to achieve (Suleiman,2004, p. 24)

\section{Theories explaining academic outstanding \\ 1- Theory of multiple intelligences}

The expansion of knowledge and the information revolution have led to the need to think about new mechanisms used by the human brain in an orderly manner so that it can comprehend, understand and think about solving the problems facing man (Mahfouz,2011, p. 71).

The theoretical idea is that the individual possesses a large number of mental potentials and aptitudes that can be expressed in more than one way through eight human intelligences that calculate the diversity of human thinking abilities, including (linguistic intelligence - social intelligence - personal intelligence) and these intelligences grow to different degrees in each person and are used in different ways in the development of skills or problem solving and this theory depends on the development of intelligences over time (Abdul-Mutty, Mustafa, 2005, p. 77).

\section{Research Methodology}

1- Research type This study is one of the library theoretical studies so that the researcher focuses on library research and scientific references as well as studies and research located within the scope of research specialization and work to present and analyze it in the light of the rules of research.

2- The method used for research The current research is based on the inductive approach of a number of studies that the researcher has been able to reach within the scope of the researcher's knowledge and the sites available to the researcher. 
3- Research tools The researcher relied on the use of the following tools:

A-Library research: Where the researcher presents the literature and theoretical heritage associated with the subject of research to reach results related to research and studies that have been interested in and have used models and theories of general practice to activate social welfare services for the academically outstanding.

B- Content Analysis Method: It includes the latest research and studies that have been interested in using models and theories of general practice in the social work to activate social welfare services for the academically outstanding

\section{Library and electronic research}

The researcher followed the following procedures for analyzing the content

Analysis framework and then relying on several sources in the analysis

- References and studies available to the researcher

- Global Research and Studies Database

- Knowledge Bank Theses Global Database

- Arabic research and studies for scientific journals and conferences for social work

4- Research time frame The researcher was able to determine the time frame of the analysis material from (2018-2000) in order to analyze the latest Arabic and foreign research and studies to determine the latest scientific models and trends to activate social welfare services for the academically outstanding, for (63) research and study, including 51 Arabic studies, 12 foreign studies.

Quantitative and qualitative analysis of scientific studies and research.

Table (1)Distribution of research and studies according to scientific form

\begin{tabular}{|l||c||c||c||c||c|}
\hline $\begin{array}{l}\text { Scientific form } \\
\text { of study }\end{array}$ & $\begin{array}{l}\text { Arabic } \\
\text { Studies }\end{array}$ & $\begin{array}{l}\text { Foreign } \\
\text { Studies }\end{array}$ & Total & percentage & Order \\
\hline \hline $\begin{array}{l}\text { Published } \\
\text { research }\end{array}$ & 18 & - & 18 & 28.57 & 3 \\
\hline PhD Thesis & 16 & 6 & 22 & 34.93 & 2 \\
\hline Master's Thesis & 17 & 6 & 23 & 36.50 & 1 \\
\hline total & $\mathbf{5 1}$ & $\mathbf{1 2}$ & $\mathbf{6 3}$ & $\mathbf{1 0 0 \%}$ & \\
\hline
\end{tabular}

It is clear from the previous table (1) on the distribution of research and studies according to the scientific form, there was a convergence in the percentages between research published in magazines and conferences and master's and $\mathrm{PhD}$ Theses, the master's Thesis came in first place by $(36.50 \%)$, followed by $\mathrm{PhD}$ Thesis in second place by $(34.93 \%)$ This may explain the researchers' interest in conducting studies and research for the academically outstanding and their interest in this category. 
Table (2)Distribution of research and studies according to year of publication

\begin{tabular}{|l|l||c||c|c|c|c||}
\hline No & $\begin{array}{l}\text { year of } \\
\text { publication }\end{array}$ & $\begin{array}{l}\text { Arabic } \\
\text { Studies }\end{array}$ & $\begin{array}{l}\text { Foreign } \\
\text { Studies }\end{array}$ & total & Percentage & Order \\
\hline \hline 1 & $\begin{array}{l}2000 \text { up to } \\
2005\end{array}$ & 6 & 2 & 8 & 12.69 & 4 \\
\hline 2 & $\begin{array}{l}2005 \text { up to } \\
2010\end{array}$ & 10 & 3 & 13 & 20.64 & 3 \\
\hline 3 & $\begin{array}{l}2010 \text { up to } \\
2015\end{array}$ & 17 & 7 & 24 & 38.09 & 1 \\
\hline 4 & $\begin{array}{l}\text { From } 2015 \text { to } \\
2018\end{array}$ & 18 & - & 18 & 28.58 & 2 \\
\hline & Total & $\mathbf{5 1}$ & $\mathbf{1 2}$ & $\mathbf{6 3}$ & $\mathbf{1 0 0}$ & \\
\hline
\end{tabular}

It is clear from the previous table (1) on the distribution of research and studies according to year of publication that from (2010 up to 2015) came in first place by (38.09\%), followed by second place (2015 to 2018) by $(28.58 \%)$, and came last from (2000 up to 2005$)$ by (12.69\%).

It is clear that a large percentage of studies and research came mostly in the time periods from 2010 up to 2015, this may be due to scientific interest by the social work profession and other professions in caring for the academically outstanding.

Table (3)Distribution of research and studies according to category of interest

\begin{tabular}{||c||r||r|r|r|r|c||}
\hline No & $\begin{array}{r}\text { category of } \\
\text { interest }\end{array}$ & $\begin{array}{l}\text { Arabic } \\
\text { Studies }\end{array}$ & $\begin{array}{l}\text { Foreign } \\
\text { Studies }\end{array}$ & total & percentage & order \\
\hline \hline 1 & $\begin{array}{l}\text { The outstanding } \\
\text { in Primary stage }\end{array}$ & 6 & - & 6 & 9.53 & 3 \\
\hline \hline 2 & $\begin{array}{l}\text { The outstanding } \\
\text { in preparatory } \\
\text { stage }\end{array}$ & 18 & 2 & 20 & 31.74 & 2 \\
\hline 3 & $\begin{array}{l}\text { The outstanding } \\
\text { in secondary stage }\end{array}$ & 27 & 8 & 35 & 55.55 & 1 \\
\hline \hline 4 & $\begin{array}{l}\text { The outstanding } \\
\text { in university }\end{array}$ & - & 2 & 2 & 3.18 & 4 \\
\hline \hline
\end{tabular}


It is clear from the previous table (3) on the category of interest that studies interested in the outstanding students in the secondary stage came in the first place by $(55.55 \%)$, followed by in the second place the outstanding students in the preparatory stage by (31.74\%), and came last the outstanding in university by $(3.18 \%)$, and this may be due to interest in the outstanding according to the stage of education.

Table (4)Distribution of research and studies according to the number of study workers (researchers)

\begin{tabular}{|c|c|c|c|c|c|c|}
\hline No & $\begin{array}{l}\text { Number of } \\
\text { researchers }\end{array}$ & $\begin{array}{l}\text { Arabic } \\
\text { Studies }\end{array}$ & $\begin{array}{l}\text { Foreign } \\
\text { Studies }\end{array}$ & total & percentage & order \\
\hline 1 & $\begin{array}{l}\text { One researcher } \\
\text { (individual) }\end{array}$ & 49 & 12 & 61 & 96.82 & 1 \\
\hline 2 & $\begin{array}{l}\text { Two researchers or } \\
\text { more (joint) }\end{array}$ & 2 & - & 2 & 3.18 & 2 \\
\hline & Total & 51 & 12 & 63 & 100 & \\
\hline
\end{tabular}

It is clear from the previous table (4) on the number of researchers conducting the research that the research carried out by one researcher for Arabic and foreign research came in the first place by $(96.82 \%)$. As for the Arabic research, this may be due to the fact that idea of the research stems from individual ideas of the researchers and therefore the researcher turns to individual research also evaluation of joint research underrates researchers because they get lower degrees than individual research.

Table (5)Distribution of research and studies according to type of study

\begin{tabular}{|c|c|c|c|c|c|c|}
\hline$\overline{\mathrm{No}}$ & $\overline{\text { Study type: }}$ & $\begin{array}{l}\text { Arabic } \\
\text { Studies }\end{array}$ & $\begin{array}{l}\text { Foreign } \\
\text { Studies }\end{array}$ & $\overline{\text { total }}$ & percentage & order \\
\hline 1 & $\begin{array}{l}\text { Descriptive } \\
\text { study }\end{array}$ & 36 & 11 & 47 & 74.61 & 1 \\
\hline 2 & evaluation study & 1 & - & $\overline{1}$ & 1.59 & $\overline{4}$ \\
\hline 3 & $\begin{array}{l}\text { Experimental } \\
\text { study }\end{array}$ & 7 & - & 7 & 11.11 & 3 \\
\hline 4 & $\begin{array}{c}\text { A quasi- } \\
\text { experimental } \\
\text { study }\end{array}$ & 7 & 1 & 8 & 12.69 & 2 \\
\hline & total & 51 & 12 & 63 & 100 & \\
\hline
\end{tabular}


It is clear from the previous table (5) on the type of study, that descriptive studies came first by (74.61\%). In second place, a quasi-experimental study by (12.69\%). And came last, an evaluation study by (1.59\%). This is consistent with the results of table (1), which is the master's Thesis came in first place by $(36.50 \%)$, which explains the interest of most researchers in descriptive studies, such as the study (Nashwa Ahmed 2015, Abir Fathi, 2013, Eman Abdul-Twab, 2016) and this may be due to the difficulty of professional intervention in schools.

Table (6)Distribution of research and studies according to theories

\begin{tabular}{|r||l||c||c|c||c|c||}
\hline No & theories & $\begin{array}{l}\text { Arabic } \\
\text { Studies }\end{array}$ & $\begin{array}{l}\text { Foreign } \\
\text { Studies }\end{array}$ & total & percentage & order \\
\hline \hline 1 & $\begin{array}{l}\text { General } \\
\text { patterns }\end{array}$ & 8 & 1 & 9 & 14.28 & 5 \\
\hline \hline 2 & $\begin{array}{l}\text { Ecological } \\
\text { patterns }\end{array}$ & 10 & 3 & 13 & 20.63 & 2 \\
\hline 3 & Role Theory & 25 & 2 & 27 & 42.85 & 1 \\
\hline 4 & $\begin{array}{l}\text { Multiple } \\
\text { intelligences }\end{array}$ & 12 & - & 12 & 19.04 & 3 \\
\hline \hline 5 & $\begin{array}{l}\text { Communication } \\
\text { theory }\end{array}$ & 2 & - & 2 & 3.17 & 6 \\
\hline \hline 6 & Not shown & 5 & 6 & 11 & 17.46 & 4 \\
\hline \hline
\end{tabular}

It is clear from the previous table (6) on Distribution of research and studies according to theories that Role Theory came in the first place by $(42.85 \%)$, followed by Ecological patterns in the second place by $(20.63 \%)$ close to Theory of multiple intelligences which got (19.04\%) and came last Communication theory by (3.17\%).

Table (7)Distribution of research and studies according to the models used

\begin{tabular}{||l||l|l|l||l|l|}
\hline Models used & $\begin{array}{l}\text { Arabic } \\
\text { Studies }\end{array}$ & $\begin{array}{l}\text { Foreign } \\
\text { Studies }\end{array}$ & total & percentage & order \\
\hline \hline Problem solving model & 30 & 3 & 33 & 52.38 & 1 \\
\hline Selective model & 1 & - & 1 & 1.58 & 5 \\
\hline \hline $\begin{array}{l}\text { Cognitive therapy } \\
\text { model }\end{array}$ & 10 & 1 & 11 & 17.46 & 3 \\
\hline
\end{tabular}




\begin{tabular}{|c|c|c|c|c|c|}
\hline task-centered model & 5 & - & 5 & 7.93 & 4 \\
\hline Not shown & 6 & 8 & 14 & 22.22 & 2 \\
\hline
\end{tabular}

It is clear from the previous table (7) on the models used that the Problem-solving model came in the first place by (52.38\%) and this may be due to the fact that the majority of studies focused on the needs, problems and pressures faced by the academically outstanding, while came last the selective model by $(1.58 \%)$.

Table (8)Distribution of research and studies according to questions and hypotheses

\begin{tabular}{||l||l|l|l|l||l||}
\hline \multicolumn{1}{|c|}{$\begin{array}{c}\text { questions and } \\
\text { hypotheses }\end{array}$} & $\begin{array}{l}\text { Arabic } \\
\text { Studies }\end{array}$ & $\begin{array}{l}\text { Foreign } \\
\text { Studies }\end{array}$ & total & percentage & order \\
\hline \hline $\begin{array}{l}\text { Questions or } \\
\text { hypotheses }\end{array}$ & 37 & 4 & 41 & 65.07 & 1 \\
\hline \hline $\begin{array}{l}\text { Questions and } \\
\text { hypotheses }\end{array}$ & 14 & 8 & 22 & 34.92 & 2 \\
\hline Total & 51 & 12 & 63 & 100 & \\
\hline
\end{tabular}

It is clear from the previous table (8) on the distribution of research and studies according to questions and hypotheses that the percentage of questions or hypotheses came in first place by (65.07\%) and in the second place, questions and hypotheses by $(34.92 \%)$ This is consistent with table (1), on the scientific form and table (5) on the type of study, and one of the studies that dealt with hypotheses and questions, the Study of Anwar Ramadan 2014.

Table (9)Distribution of research and studies according to the type of method used

\begin{tabular}{|l|l|l|l||l|l|}
\hline Method used: & $\begin{array}{l}\text { Arabic } \\
\text { Studies }\end{array}$ & $\begin{array}{l}\text { Foreign } \\
\text { Studies }\end{array}$ & total & percentage & Order \\
\hline \hline Social Survey & 37 & 12 & 49 & 77.77 & 1 \\
\hline \hline Experimental & 7 & - & 7 & 11.11 & 2 \\
\hline Quasi-experimental & 7 & - & 7 & 11.11 & 2 bis \\
\hline \hline Total & $\mathbf{5 1}$ & $\mathbf{1 2}$ & $\mathbf{6 3}$ & $\mathbf{1 0 0}$ & \\
\hline
\end{tabular}

It is clear from the previous table (9) on the type of method that the social survey method came in the first place by $(90.92 \%)$, followed in the second place by the experimental method that is equal to the quasi-experimental method by $(11.11 \%)$ and this is consistent with the results of table (5) on the type of study. 
Table (10)Distribution of research and studies according to the tools used

\begin{tabular}{|l||l|l|l||l|l|}
\hline Tools & $\begin{array}{l}\text { Arabic } \\
\text { Studies }\end{array}$ & $\begin{array}{l}\text { Foreign } \\
\text { Studies }\end{array}$ & total & percentage & Order \\
\hline \hline Questionnaire & 18 & 9 & 27 & 42.85 & 2 \\
\hline \hline $\begin{array}{l}\text { interviewing } \\
\text { Schedule }\end{array}$ & 2 & - & 2 & 3.17 & 4 \\
\hline Scale & 46 & - & 46 & 73.01 & 1 \\
\hline Interview guide & 1 & 4 & 5 & 7.93 & 3 \\
\hline
\end{tabular}

It is clear from the previous table No. (10) on the distribution of research and studies according to the tools used that the tools varied between a questionnaire, a scale and an interviewing Schedule and that there are many studies which used more than one tool to collect data, in the first place came the scale by $(73.01 \%)$ and this may be due to the type of study and the accuracy of the scale in the collection and analysis of data, followed in the second place by the questionnaire by (42.85\%) and came last the interviewing Schedule by (3.17\%) and this is consistent with table (3) on the category of interest where secondary students came in first place by $(55.55 \%)$.

Table (11)Distribution of research and studies according to the research language

\begin{tabular}{|l|l|l|l|}
\hline research language & total & Percentage & order \\
\hline \hline Arabic Research & 51 & 80.95 & 1 \\
\hline \hline Foreign Research & 12 & 19.05 & 2 \\
\hline total & 63 & 100 & \\
\hline
\end{tabular}

It is clear from previous table (11) on the distribution of research and studies according to the language of the study that Arabic Research came in the first 
place by (80.95\%), followed in the second place by foreign research by $(19.05 \%)$ This explains the local interest in research and the importance of the category of the outstanding.

Table (12)Distribution of research and studies according to studies and research classification

\begin{tabular}{|c||c||c||c||c||c|}
\hline Classification of studies & $\begin{array}{c}\text { Arabic } \\
\text { Studies }\end{array}$ & $\begin{array}{c}\text { Foreign } \\
\text { Studies }\end{array}$ & total & percentage & Order \\
\hline \hline $\begin{array}{c}\text { local Classification of } \\
\text { studies and research }\end{array}$ & 27 & - & 27 & 42.86 & 1 \\
\hline \hline $\begin{array}{c}\text { Regional classification } \\
\text { of studies and research }\end{array}$ & 24 & - & 24 & 38.09 & 2 \\
\hline \hline $\begin{array}{c}\text { Global classification of } \\
\text { studies and research }\end{array}$ & - & 12 & 12 & 19.05 & 3 \\
\hline \hline Total & 51 & 12 & 63 & 100 & \\
\hline
\end{tabular}

It is clear from the previous table (12), on the distribution of research and studies according to studies and research classification that the studies and research published locally came in the first place by (42.86\%), followed in the second place by the studies and research published globally by (38.09), and came last, regionally, by (19.05\%). This explains the interest in the category of the academically outstanding, and this may be due to the interest of researchers in the local community, unlike global and regional research and studies.

Table (13)Distribution of research and studies according to the objectives of studies and research

\begin{tabular}{|c||c|c|c||c|c||}
\hline $\begin{array}{c}\text { Objectives of } \\
\text { the study }\end{array}$ & $\begin{array}{c}\text { Arabic } \\
\text { Studies }\end{array}$ & $\begin{array}{c}\text { Foreign } \\
\text { Studies }\end{array}$ & total & percentage & order \\
\hline \hline $\begin{array}{c}\text { Theoretical } \\
\text { objectives }\end{array}$ & 28 & 6 & 34 & 53.96 & 1 \\
\hline \hline $\begin{array}{c}\text { Practical } \\
\text { objectives }\end{array}$ & 23 & 6 & 29 & 46.04 & 2 \\
\hline
\end{tabular}




\section{Total}

It is clear from the previous table (13) on the distribution of research and studies according to the objectives of the study that the theoretical objectives came first by $(53.96 \%)$, followed in the second place by Practical objectives by (46.04\%).

\section{Second: qualitative analysis of studies and research}

A group of studies that conducted general theories in social work and focused on the theory of general systems and the theory of patterns, Jumaa Fathy study, where I was interested in studying the relationships between personal, family, school and societal variables of personal compatibility for students who excel academically Wagdy Mohamed Barakat, who was interested in studying the problems of high achievers and learning about the care provided to them, Mahmoud Helmy Sanad study, a tent aimed at determining the level of professional performance of the social worker in dealing with outstanding students and relying on an external model and effectiveness.

Anwaar Ramadan Mohammad study, which focused on determining the level of effectiveness of social care services for outstanding students, which concluded that the level of services was average. Also, relying on the efficiency and effectiveness model. It was found from the results of some studies and research that they were interested in using the cognitive therapy model and testing its effectiveness in alleviating the problems and pressures of outstanding and academically superior students. As a study by Mamdouh Mohamed Desouky, which concerned itself with alleviating the psychological stress of outstanding students to treat some of the motives and causes that lead to the occurrence of stress by increasing the students awareness of their actions and behaviors.

Studies that focused on the selective model, such as the study of Muhammad Abdul Hamid Sharshir, which focused on using a selective model to alleviate the problems facing outstanding students in their relationships with their colleagues in the school, curricula, teachers and school administration.

Studies that focused on using the problem-solving model, such as the study of Muhammad Abdul Hamid Al Kaabi, which focused on studying the needs of academically outstanding students and how social service contributes to satisfying these needs, and the study of Nashwa Ahmed Muhammad, which focused on identifying the problems facing outstanding students and determining the role of the social specialist in facing those problems and identifying the difficulties that they face. face it and develop a proposed vision for the role of the social worker to overcome these difficulties.

Through the previous presentation of the types of local and international scientific studies and research available from different sources related to the current subject of the study, the researcher reached the following results related to the objectives of the research 
Most studies were interested in the category of the outstanding students in the secondary stage. This may be due to the fact that there has been a secondary school for the outstanding in Cairo in the time of 2000/2018, which reflects the orientations of the state to give due attention to the outstanding to maintain their superiority. Individual research got the largest percentage since most studies are Master's and PhD Theses. Some studies were interested in using the theory of multiple intelligences due to the importance of determining differences between students in intelligence levels and discovering creative abilities and skills such as the study (Nashwa,2015). Many studies also relied on a model or a theory in accordance with the research such as communication theory or general patterns or ecological patterns and this is considered one of the theories facing researchers in conducting research, and the theory is chosen in accordance with the nature of the research and its objectives. Many studies also relied on the model of problem solving or Cognitive therapy or the selective model. Analysis of the studies also showed that there are many studies that have confirmed the normality of social welfare services provided to outstanding students, which consisted of psychological, social and educational services such as the study (Al-Sayed 2015). Some studies also were interested in assessing the needs of the academically outstanding and studying their problems. Some studies were concerned with the professional competence of the social workers such as the study( Sahar 2003 and Norhan 2003).

\section{General conclusions and findings of the research}

Through the quantitative and qualitative analytical presentation of the latest local and international research based on models and theories of general practice in social work to activate social welfare services for the academically outstanding. The researcher reached the following general results:

- The studies and research surveyed by the researcher did not focus directly on models and theories of general practice in social work.

- The small number of local and international studies and research surveyed by the researcher who dealt with models and theories of general practice in the social work to activate social welfare services for the academically outstanding.

- Many studies and research surveyed by researchers were more interested in studying the needs and problems of outstanding students than professional intervention with the category of the academically outstanding.

-Several local studies have come up with a proposed vision or program to activate social welfare services for the academically outstanding.

-Foreign studies have been interested in studying the characteristics and needs of the academically outstanding.

\section{Research recommendations}

The need to conduct research and studies related to the general practice in the social work by dealing with all the practice patterns using models and theories of general practice to activate social welfare services for the academically outstanding. 
- The importance of employing models and theories in the field reality of the academically outstanding because they are considered to be a guide for the study and using them in interpreting and analyzing the results.

Giving great importance to the practice of social work with the academically outstanding and work to apply models and theories infield practice and help to deal with the practice patterns and stay away from interfering with general practice due to its wide range to reach accurate results.

- Researchers should be careful that models, approaches and theories do not overlap.

\section{References}

Abdul-Mutty, A. H \& Mustafa, D. M. (2005). Life Skills, Cairo, Al-Sahab Publishing House.

Abdul-Maksoud, E. A.(2016). Comparative Study of the problems of outstanding students in both public and private schools from the perspective of general practice in social work, unpublished master's thesis, Helwan University, Faculty of Social Work.

Abdul Wahid, A. F . (2013). The role of community worker with groups of the academically outstanding to solve environmental problems in the school community, unpublished master's thesis, Helwan University, Faculty of Social Work.

Abo-AlMaaty ,A. M.(2009). Modern trends in social work and welfare, Cairo: Noor El-Eman for Printing.

Barker, R. (1999). The Social work Dictionary Washington, NASW, Press.

El-Sayed, A. R (2015). Effectiveness of social welfare services for outstanding students in boarding schools from the perspective of general practice in social work, research published in the Journal of Social Workers, Issue 54, Part 8, 2015

Gaddafi, R. M. (2000). Caring for the talented and the creative ,Alexandria: Modern University Office.

Germain, C. B. \& Gitterman. A. (1980) The life Model of Social Work Practice, Advances in Theory Practice,NewYork,Columbia University.

Habib, G. Sh. (2014). General practice in the field of school, Gamal Shehata et al.: general practice of social work in the field of youth welfare and the school field (Helwan University: University Book Publishing and Distribution Center.

Mansour, M. b \& Ahmed, A. S.(2000). The Talented prospects for care and rehabilitation between the Arab and scientific realities, Riyadh: Obeikan Office 
Mahfouz, M. A. (2011). Basic and innovation theories, and professional models on the way of dealing with groups, Cairo, Dar al-Eman.

Mabrouk ,S. F. (2003). Professional skills of the social worker in the discovery and care of the talented, published research at the 16th Scientific Conference, Helwan University,

Mohammed, M. A. (2014). General practice in social work in the school field, Alexandria, Modern University Office

Munir, N. (2003). Towards more effectiveness of the worker's role with talented children's groups to develop their creative abilities, research published at the 16th Scientific Conference, Helwan University, Faculty of Social Work.

Ragab, A.,A. (2003). Educational care for people with special needs, Cairo, Al Fagr Publishing and Distribution House.

Sayed F. M. (2001). Approach to school social work, Alexandria: Modern University Office

Shaaban, N. A.(2015). A proposed vision of the role of the way of dealing with groups to alleviate the problems of outstanding students arising from residence in boarding schools, an unpublished master's thesis, Helwan University, Faculty of Social Work.

Suleiman, A.S. \& Munib, T. M.(2008). The outstanding, the talented and the creative, Cairo, Anglo-Egyptian Bookshop.

Suleiman, A.S. (2004). The mentally outstanding - their characteristics - discovering them- their upbringing and problems, Cairo, Zahraa Al-Sharq Office.

Wahba M. M. (2007). The Talented and the outstanding. methods of discovering and caring of them, the global experiences of Alexandria, Dar al-Wafaa, the world of printing and publishing.

Zahran, H. A. (2003). Studies in Mental Health and Psychological Guidance (Cairo: The World of Books. 